\title{
THE CROSSING OF THE JORDAN ACCORDING TO JOSEPHUS
}

\author{
C. Begg ${ }^{1}$
}

\begin{abstract}
This study offers a detailed examination of Josephus' retelling (in Ant. 5.16-21) of the account of Israel's crossing of the Jordan and its immediate sequels found in Joshua 3-5. The investigation uncovers (limited) indications of Josephus' use of various textforms of the biblical passage. It also calls attention to the range of rewriting techniques applied by Josephus to the source narrative (abbreviations, amplifications, rearrangements, and other modifications) which result in a version of events that is, e.g., much more compact than the biblical one, even while it nuances the portrayal of the story's characters in a number of respects.
\end{abstract}

\section{INTRODUCTION}

Joshua 3:1-5:15 tells, in much circumstantial and confusing detail, of the Israelites' crossing the Jordan and the immediate sequels to their arrival in the Cisjordan. ${ }^{2}$ In this article I propose to investigate Josephus' (much compressed) version of these events in his Antiquitates judaicae (hereafter $A n t$.$) 5.16-21. { }^{3}$ I undertake this essay with two overarching questions in mind: (1) Given the differences among the various ancient witnesses for Josh. 3:1-5:15, i.e. MT (BHS), the Qumran manuscript 4QJosh ${ }^{\mathrm{b}}{ }^{4}$ Codex Vaticanus (hereafter B) of the LXX, ${ }^{5}$ the Vetus Latina (hereafter VL), ${ }^{6}$

1 Prof. Christopher Begg, Professor of Old Testament, Catholic University of America, Washington; and Research Associate of the Department of Old Testament Studies, University of Pretoria. E-mail: begg@cua.edu.

2 On the (textual, historical-critical, etc.) problems posed by Josh. 3:1-5:15, see Boling \& Wright (1982:153-199).

3 For the text and translation of Ant. 5.16-21 I use Marcus (1934:8-11). I have further consulted the relevant text, translation, and notes of Nodet (1995:118-120*) and the annotated translation of Begg (2005:6-7).

4 This manuscript preserves (parts of) Josh. 3:15-4:3. For the text, see Ulrich et al. (1995:155) and for the translation Abegg et al. (1999:203-204).

5 For the text of B Josh. 3:1-5:15, I use Brooke \& Maclean (1917:681-690). I have also consulted the translation of and notes on this text in Moatti-Fine (1996:105-121).

6 For the VL text of Josh. 3:1-5:15, I use Robert (1900:56-61). 
the Vulgate (hereafter Vg.), ${ }^{7}$ and Targum Jonathan of the Former Prophets (hereafter Tg.), ${ }^{8}$ where do Josephus' textual affinities in Ant. 5.16-21 lie?, and (2) What sorts of rewriting techniques has the historian applied to the data of his $\operatorname{Vorlage}(n)$ and what is distinctive about his own version as a result of their application?

To facilitate my comparison of them, I divide up the material of Ant. 5.16-21 and Josh. 3:1-5:15 into four parallel segments as follows: Preparations for crossing (5.16//3:1-13*); Crossing completed (5.17$19 / / 3: 2,14-17 ; 4: 18)$; Stones erected (5.20a//[3:12; 4:1-10a]; 4:2024); and Passover \& cessation of manna (5.20b-21//5:10-12).

I conclude this introduction with a word concerning the respective common contexts of Josh. 3:1-5:15 and Ant. 5.16-21. Both segments are preceded by the account of the visit of the Israelite spies to Rahab in Jericho (Josh. 2:1-24//Ant. 5.2-15). ${ }^{9}$ Both likewise have as their immediate continuation the story of the miraculous overthrow of Jericho (Josh 6:1-27//Ant. 5.22-32). ${ }^{10}$

\section{PREPARATIONS FOR CROSSING}

Following the notice on Israel's approach to the Jordan in Josh. 3:1, $3: 2-13$ prefaces Israel's actual crossing of the river with a whole series of directives issued by various authorities to different hearers regarding the upcoming crossing. The series begins with words to the people by the "officers" (3:2-3) and by Joshua (3:5), continues with Joshua's injunction to the priests (3:6), followed by the Lord's communication to Joshua (3:7-8), and ending with a further proclamation by Joshua to the people (3:9-13). Josephus, as pointed out in n. 9, anticipates his equivalent to

7 For the targumic text of Josh. 3:1-5:15, I use Sperber (1959:4-8) and for the translation Harrington \& Saldarini (1987:21-25).

8 For the text of B Josh. 3:1-5:15, I use Brooke \& Maclean (1917:681-690). I have also consulted the translation of and notes on this text in Moatti-Fine (1996:105-121).

9 In his version of Joshua 2 in Ant. 5.2-15 Josephus works in elements drawn from the preceding and following context of Joshua. Specifically, in 5.3-4 he fills in the interlude during which the Israelites are awaiting the spies' return from Jericho with a version of Josh. 1:12-18 (//5.3-4a [Joshua's exchange with the Transjordanian tribes]) and 3:1 (//5.4b [Israel's advance to the banks of the Jordan under Joshua's leadership]). On Josephus' retelling of Joshua 2, see Begg (2005).

10 On Josephus' version of Joshua 6, see Begg (2005:323-340). 
the notice of 3:1 on Israel's advance to the Jordan to an earlier moment in his own presentation; see $5.4 \mathrm{~b} .{ }^{11}$ Having done so, he now (5.16) offers a substitute content for the concatenation of discourses found in 3:2-13 (see above). This substitute opening for the crossing segment, inter alia, explains why the divine intervention promised in 3:7-8 was necessary to enable Israel to cross a relatively minor stream. ${ }^{12}$ It reads:

Now since the army was afraid ( $\delta \in \delta$ เóTOS) to cross the river, which had a strong current ( $\dot{\rho} \in \dot{u} \mu a \mathrm{Tl}$ ) and could not be crossed by bridges — for it had not been spanned by any hitherto, and should they wish to lay them now, the enemy would not, they imagined, afford them the leisure, and they had no ferry-boats ${ }^{13}$ - God ${ }^{14}$ promised to render the stream passable ( $\delta \mathrm{\iota} \alpha \beta a-$ Tóv) for them by diminishing its volume. ${ }^{15}$

11 This reads: “... he [Joshua] with fifty thousand men-at-arms set out from Abele and advanced sixty stades towards the Jordan." Compare Josh. 3:1: "Early in the morning Joshua rose and set out from Shittim with all the people of Israel [the words with... Israel are absent in LXX]; and they came to the Jordan." (Biblical translations follow the RSV.) Josephus' inserted figure concerning the number of the Israelite combatants anticipates and amplifies that given in Josh. 4:13, i.e. "about 40,000 armed ready for war." As for Israel's starting point, Josephus' form "Abele" (compare Bible "Shittim") is an abbreviation of the site's full name, i.e. "Abel-shittim" cited in Num. 33:49. Finally, as often, Josephus supplies an indication (60 stades) concerning the distance between the two points in question for the benefit of readers unfamiliar with Palestinian geography.

12 See Nodet (1995:119, n.1) who speaks of Josephus' remarks in 5.16 as "explications embarrassées."

13 The above sequence (throughout this essay I italicize such elements of Josephus' presentation which lack a clear-cut biblical parallel) provides an explanation of the opening mention of the people's "fear": given the absence of bridges over the Jordan (and the unlikelihood that any could be built at this point in the face of enemy resistance) as well as the non-availability of ferry-boats, the only way for the Israelites to get across the stream was on foot, the frightfully strong current notwithstanding. Taken as a whole, Josephus' formulation serves to highlight the magnitude of the logistical problem facing Israel's leader Joshua (and ultimately God himself), but also their success in resolving it.

14 In Josh. 4:7a a it is "the Lord" who speaks to Joshua. On Josephus' virtually total avoidance of the LXX's use of Kúpıos as divine title, this likely due to the noncurrency of such a usage in secular Greek, see Begg (1993:45, n. 218). The divine words of $4: 7 \mathrm{a} \beta \mathrm{b}-8$ are formulated in direct address. In line with his frequent practice, Josephus recasts them in indirect discourse; on the phenomenon, see Begg (1993:12-13, n. 38).

15 Josephus' version of the divine words differs markedly from those cited in Josh. 


\section{CROSSING COMPLETED}

Having drastically condensed the Bible's detailed presentation $(3: 1-$ 13) of the preparations for the crossing in 5.16, Josephus (5.17-19) does go into somewhat great detail in recounting the crossing itself, drawing selectively on various biblical data concerning this. He begins (5.17) the new segment with a delayed utilization of the time indication of $3: 2$ ("after three days," the officers issue directives [see 3:3-4] to the encamped Israelites): "So Joshua, having waited two ${ }^{16}$ days...." He then continues with a detailed description, expatiating on the indications of 3:14, of the line of march adopted by the Israelites, at Joshua's direction, for their crossing:

... (Joshua) proceeded to transport the army with the whole multitude in the following fashion. ${ }^{17}$ At the head went the priests bearing the ark, ${ }^{18}$ next the Levites carrying the tabernacle and the vessels for the ministry of the sacrifices, ${ }^{19}$ and, after the Levites, followed, tribe by tribe, the whole throng,

4:7-8, where the Lord promises to "magnify Joshua" (v. 7) and gives him instructions about the priests' standing still at the Jordan's brink (v. 8). In fact, his rendering of God's promises here reads like an attenuated rendering of Joshua's own announcement to the people in Josh. 3:13b (MT): "[T]he waters of the Jordan shall be stopped from flowing, and the waters coming down from there shall stand in one heap." As Marcus (1934:8-9, n. b) and Nodet (1995:119, n. 2) point out, Josephus' wording regarding what is to happen with the water downplays the miraculous element involved: the stream is only to be diminished, not stopped and gathered in a heap.

16 Nodet (1995:119, n.3) suggests that Josephus' figure here reflects a misreading of the MT form שלשת in 3:2.

17 This notice, with its accentuation of Joshua's leadership role, lacks a counterpart in Joshua 3.

18 Compare Josh. 3:14: “... with the priests bearing the ark of the covenant before the

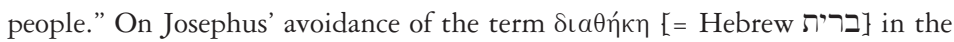
sense of "covenant" which recurs as part of the designation for the ark throughout Joshua 3-4, see Begg (1993:100-101, n. 609).

19 No such distinct role is assigned to the Levites in contrast to the ark-bearing priests in Joshua 3. Josephus' attribution of a separate task to the former group is perhaps inspired by the LXX (and VL) reading in Josh. 3:3 which refers to "the priests and Levites" bearing the ark, whereas in MT (and Vg., Tg.) the reference is to the "Levitical priests" (הכהנימ הלוים) as the ark's carriers. Whereas, however, LXX and VL (as does also Origen, Homilies on Joshua 4.3 [see Jaubert (1960:155]) represent both groups as carrying the ark, Josephus assigns the Levites distinct 
with the women and children in the centre, ${ }^{20}$ for fear ( $\left.\delta \in \delta \mathrm{u} \omega \mathrm{s}\right)$ of their being swept away by the force $\left(\beta\llcorner a \sigma \theta \in \hat{\epsilon} \in \nu)\right.$ of the current.$^{21}$

After the foregoing description of the line of march adopted by the Israelites for the crossing, Josephus (5.18-19) goes on to relate the actual movements of priests and people. Speaking first of the former group, he elaborates (5.18a) on the allusion of $3: 15$ to the priests' initial contact with the stream:

When the priests, who were the first to enter, found the river fordable (торєUто́s) - the depth having diminished ${ }^{22}$ and the shingle (кóx-

objects to carry in accord with his notice in Ant. 3.258 (cf. Num 3:8,25, 31) where Moses entrusts the "tabernacle and the sacred vessels" to the Levites, the carrying of the ark having earlier (see 2.136) been confided to the priests. On Josephus' overall portrayal of the Levites, see Begg (2004:1-22). Finally, note the remark attributed to the rabbis in $b$. Sot. $33 \mathrm{~b}$ that although the carrying of the ark was normally the responsibility of the Levites (see, e.g., David's directive to this effect in $1 \mathrm{Chr}$ 15:2), the priests carried it on three occasions, the first of these being the crossing of the Jordan.

20 In, e.g., Josh. 3:14 only two groups of marchers are distinguished, i.e. the priests who lead the procession and the people who follow them. Josephus gives a more differentiated picture of the procession's component groups: priests, Levites, the (remaining) tribes each marching as a unit, with the women and children placed in the middle of the line of march.

21 These concluding words of 5.17, which provide a motivation for the placement of the women and children as cited in what precedes, echo the opening of 5.16: " $[\mathrm{N}]$ ow since the army feared ( $\delta \in \delta$ เóTos) to cross the river, which had a strong current $(\rho \in \dot{u} \mu a \tau \iota)$....” In both instances, Josephus highlights the fear-inspiring obstacle posed by the Jordan (and, conversely, God's ability to dispose of this); see n. 12 .

22 This formulation echoes the promise Josephus attributes to God in 5.16b, i.e. "to

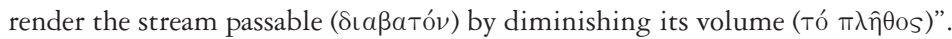
The (mere) diminution of the river's flow, announced in 5.16, and realized in 5.18 , contrasts with the more spectacular happening predicted by Joshua in 3:13 (see n. 14) and brought about in 3:16a (MT): “... [W] [Waters coming down from above stood and rose up in a heap far off, at Adam, the city that is beside Zarethan, and those flowing down towards the sea of the Arabah, the Salt Sea were entirely cut off." Josephus likewise omits the parenthetical chronological notice at the end of 3:15 ("the Jordan overflows all its banks throughout the time of $[++$ wheat, LXX VL 4QJos ${ }^{\mathrm{b}}$ ] harvest”). 
$\left.\lambda \eta \kappa_{0}\right),{ }^{23}$ which the current was neither full nor rapid enough to force ( $T \hat{n}$ $\beta\left(\mathbf{c}^{\alpha}\right)^{24}$ from under their feet, lying as a solid floor ... ${ }^{25}$

The priests' unimpeded advance, in turn, is followed by that of the people: ... all thereupon confidently $\left(\theta a \rho \sigma a \lambda \hat{e}^{\omega} \omega\right)^{26}$ traversed the stream, perceiving it to be even as God had foretold that He would make it. ${ }^{27}$

Josephus rounds off (5.19) his account of the crossing with notices on the priests' holding their position until the process is completed and the river's return to its normal state once they reach land. His rendering of these items runs:

But the priests stood still in the midst until the multitude had crossed and reached the firm ground. ${ }^{28}$ Then, when all had crossed, the priests emerged, ${ }^{29}$ leaving the stream free to resume its accustomed course. And the river, so soon as the Hebrews ${ }^{30}$ had quitted it, swelled and recovered its natural magnitude. ${ }^{31}$

23 The word кá $\chi \lambda \in \zeta$ ("pebble, river gravel") is hapax in Josephus.

24 This noun echoes the verbal form $\beta \iota a \sigma \theta \in \hat{\imath} \in \nu$ used in 5.17 of the current's "sweeping away" the women and children.

25 With the above notice Josephus seems to conflate the Bible's double reference to the priests' activities during the crossing in 3:15 (the priests "dip their feet in the brink of the water") and 3:17 (the priests "stand on dry ground in the midst of the Jordan" until all have passed over).

26 Josephus inserts this reference to the people's state of mind as they ford the stream. The insertion calls attention to the transformation of the people's inner state: previously (see 5.16-17) they were "fearful" of the current; now they "confidently" advance into it.

27 Josephus appends this allusion to the people's "perception" to the notice on their "passing over" of 3:16b. The appendix highlights the fulfillment of the divine promise of $5.16 \mathrm{~b}$ and helps explain the people's new-found "confidence" mentioned in what precedes.

28 In the biblical account this fact is reported twice; see 3:17 and 4:10.

29 Josephus here simplifies the presentation of Josh. 4:15-18a where the priests' coming up out of the water (v. 18a) is in response to a directive by Joshua (v. 17) who himself is relaying a divine command on the matter (vv. 15-16).

30 On Josephus' use of the designation "Hebrew(s)" at the various moments of his history, see Harvey (1996:124-129).

31 Compare Josh. 4:18b: “([O]nce the priests' feet touch dry ground) the waters of the Jordan returned to their place and overflowed all its banks, as before." The river's "swelling" at this point is the reversal of its diminution spoken of in 5.16 and 18 . 


\section{STONES ERECTED}

The narrative of Joshua 3-5 relates five events that follow Israel's exit from the Jordan: erection of memorial stones, the fear of the native kings before Israel, the circumcision of the people, celebration of the Passover and cessation of the manna, and Joshua's encounter with "the commander of the Lord's army." Of the five happenings, Josephus has some equivalent only to the first and fourth in 5.20-21. Joshua 3-4 devotes considerable (and repetitious) attention to the memorial stones that are erected once Israel's crossing has been completed; see 3:12; 4:1-9,32 19-24. Josephus markedly compresses the biblical data on the stones, ${ }^{33}$ while also interjecting elements of his own concerning them in 5:20a:

These [i.e. the Hebrews of 5.19 in fine], having advanced fifty stades, 34 pitched their camp at a distance of ten stades ${ }^{35}$ from Jericho. ${ }^{36}$ And Joshua, with the stones which each of the tribal leaders $\left(\phi v \lambda \alpha \rho^{\prime} \chi \omega \nu\right)^{37}$ had, by the prophet's (тои профи́тоu) ${ }^{38}$ orders, ${ }^{39}$ taken up from the river

32 Josh. 4:9 introduces a parenthetical reference to a second set of stones (called "other stones" in LXX VL and Vg.) that, in contrast to the stones spoken of elsewhere in Joshua 3-4, are erected by Joshua in the Jordan itself. Josephus' account of the stones in 5.20a makes no reference to this second set.

33 In particular, he passes over the segment 4:1-7 featuring directives by the Lord to Joshua (vv. 2-3) and of Joshua to the twelve designated stone-carriers (vv. 4-7) that are pronounced once Israel has completed its crossing (v. 1).

34 This specification concerning the distance traversed by the people following their exit from the Jordan (compare the similar, likewise inserted mention of the Israelites' "advancing sixty stades towards the Jordan" in 5.4b; see n. 11) lacks an equivalent in Josh. 4:19. Conversely, that verse provides a dating ("on the tenth day of the first month") for Israel's passage to which Josephus has no parallel.

35 Also this distance indication is without parallel in Josh. 4:19.

36 Compare the indications concerning Israel's camp-site in 4:19b: "[T]hey encamped in Gilgal on the east border of Jericho." Josephus makes a "delayed" reference to "Galgala" as the camp-site established by Joshua in Ant. 5.34. See also n. 45.

37 In Josh. 4:4-7 Joshua directs his instructions concerning the stones to "twelve men from the people of Israel, whom he had appointed, a man from each tribe" (v. 4). Josephus' version does not utilize the biblical figure (twelve) either for the tribal representatives nor for the stones they collect.

38 The Hebrew Bible itself does not explicitly apply the prophet title to Joshua; Josephus does so twice elsewhere; i.e. Ant. 4.165,311. See Feldman (1998:447). The historian's procedure in this regard is in line with his more general tendency to introduce the title in contexts where the Bible lacks it, on which see Feldman 


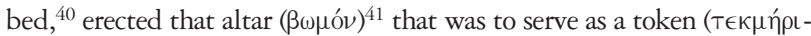
$o v)^{42}$ of the stoppage of the stream ${ }^{43}$ and sacrificed thereon to God. ${ }^{44}$

(1990:388-391). Compare Sir 46:1 where Joshua is called Moses' "successor in prophesying בנבואה)." Cf. also Eupolemus (apud Eusebius, Praep. ev. 9.30.1) who states:

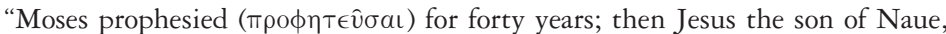
thirty years."

39 With this term Josephus alludes to the extended directives concerning the stones which Joshua imparts to the twelve tribal representatives in 4:4-7.

40 This phrase summarizes the more expansive narration of 4:8a: "And the men of Israel did as Joshua [MT; LXX: the Lord] commanded, and took up twelve stones out of the midst of the Jordan, according to the number of the tribes of the people of Israel, as the Lord told Joshua [see 4:2]." Josephus leaves aside the attached notice of $4: 8 \mathrm{~b}$ : "[A]nd they carried them over to the place where they lodged, and laid them down there."

41 Compare Josh. 4:20: "And those twelve stones which they [MT; LXX: he, i.e. Joshua] took up out of the Jordan, Joshua set up in Gilgal.” Josephus' indication that the stones were set up as an "altar" seems to be inspired by (and represent a conflation of) the Mosaic directives in Deut 27:1-8 (//Ant. 4.305-308) where the Israelites "on the day you pass over the Jordan to the land the Lord... gives you" (v. 2a) are commanded to set up "large stones" (v. 2b) and to build an "altar" (v. 5) on Mount Ebal (v. 4). In both the MT and LXX of Joshua, the fulfillment of these commands (8:30-35, MT) comes at a much later point, in MT after 8:1-29 (the capture of $\mathrm{Ai}$ ), in LXX after 9:1-2 (the gathering of the native kings against Israel). Josephus' "anticipated" (partial) realization of the commands here in 5.20 (he gives a fuller version of their fulfillment following his version [5.68] of Josh. 18:1 [the erection of the tabernacle at Shiloh] in 5.69-70) does, however, have an (apparent) parallel in 4QJosh ${ }^{\mathrm{b}}$ where the manuscript's rendition of MT Josh. 8:34-35 (i.e. the conclusion to the account of the execution of Moses' orders in MT 8:30-35) stands prior to its version of Josh. 5:2-7 (the circumcision of the people). PseudoPhilo (L.A.B. 21), for his part, attaches his version of Josh. 8:30-35 (vv. 7-10) to his parallel (vv. 1-6) to Josh. 13:1-6 (God's words to the aged Joshua), while in b. Sot. 36a all the events of Joshua 3-5; 8:30-35 are assigned to a single, very busy day on which the Israelites cross the Jordan, advance to Mounts Gerizim and Ebal (a distance of "more than sixty mil"), panicking the kings en route (see Josh. 5:1), perform the operations spoken of in Josh. 8:30-35, pack up the stones they had brought with them from the Jordan, and return to their camp at Gilgal (see Josh. 4:19). On the whole topic, see Ulrich (1995:145-146) and Begg (1997:294-314).

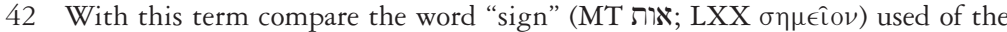
stones by Joshua in 4:6 in the context of his initial statement concerning their significance (4:6-7), a passage not reproduced by Josephus. 
In the sequence of Joshua 4-5 the account of the erection of the stones (4:19-24) is followed by notices on the fear of the native kings (5:1) and a "second" (so MT 5:2, > LXX VL) circumcision of the Israelites (5:2-7). Josephus has no parallel to either of these items. ${ }^{45}$ Instead, he proceeds immediately to his version of the fourth of the post-crossing events featured in Josh. 4:19-5:15, i.e. the celebration of the Passover and the cessation of the manna.

\section{PASSOVER \& CESSATION OF MANNA}

Josh. 5:10-11 summarily relates the first Passover celebrated in the land of Israel. Josephus' (equally brief) version (5.20b-21a) of the happen-

43 With this phrase Josephus sums up Joshua's extended disquisition concerning the newly erected stones in 4:21-24 (which itself parallels his earlier words on the subject in 4:6-7): to their children's future question about the meaning of the stones (v. 21), the Israelite parents are to reply by telling them of the Lord's great deed of drying up the Jordan as he had the Red Sea (vv. 22-23), this to the end that the other peoples might "know" the Lord's power and Israel might "fear" the Lord (v. 24).

44 This reference to Joshua's "sacrificing" on the "altar" just erected by him continues Josephus' "anticipation" of the fulfillment of the Mosaic directives of Deut. 27:1-8 (//Ant. 4.305-308) where (v. 6b-7a//4.308) the Israelites, are enjoined to offer holocausts and peace-offerings on the altar (see vv. 5-6a) they are to erect once they cross the Jordan. See n. 40.

45 His omission of 5:1 might be due to the verse's seemingly digressive character in a context (4:19-5:15) focussed on the Israelites' own experiences. As for his non-utilization of the circumcision account of 5:2-9, various factors might help to account for this: the passage's implication that a key practice of Israel's religion had been neglected during the people's time in the desert (so Spilsbury [1998: 149 , n. 114]) and/or its suggestion of a compulsory, non-consensual circumcision of all the Israelites, a point likely to reinforce Roman concerns about the supposed aggressiveness of Jewish religiosity (so Feldman [1998:445]). Finally, note that 5:2-9 concludes in 5:9 with a etiological wordplay on the name Gilgal that begins with the Lord saying to Joshua: "This day I have rolled away (גלותי) the reproaches of Egypt from you" and then continues "And so the name of that place is called Gilgal (גלגל) to this day." As mentioned in n. 36, Josephus makes his first mention of "Gilgal" ( $\Gamma \alpha ́ \lambda \gamma \alpha \lambda \alpha)$ only in 5.34, there supplying his own explanation

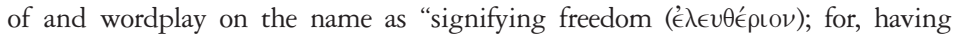
crossed the river, they [the Israelites] felt themselves free ('̇ $\lambda \in \cup \theta \epsilon$ f́pous) both from the Egyptians and from their miseries in the desert." 
ing omits certain of the biblical particulars concerning it, while also interjecting others peculiar to himself. It reads:

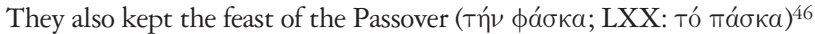
at that spot, ${ }^{47}$ being now readily and amply provided with all that they lacked

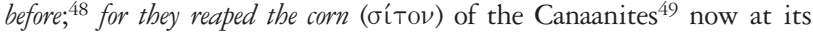

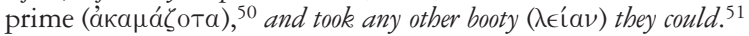

Josh. 5:12 complements 5:11's reference to the Israelites' new source of food in the land with mention of the cessation of their desert nourishment, the manna. To his reproduction of this notice in 5.21b Josephus adds a reminiscence, inspired by Exod 16:35//Ant. 3.32, of the duration of the manna's bestowal:

46 On Josephus' treatment of the Passover observance throughout his corpus, see Colautti (2002).

47 I.e. the site "at a distance ten stades from Jericho" where the Israelites encamped after exiting the Jordan according to 5.20a. Josh. 5:10 (MT) provides a double, more specific localization of the Passover observance, i.e. "in Gilgal $[>\mathrm{LXX}] \ldots$ in the plains of Jericho (LXX: to the west of Jericho on the opposite side of the Jordan in the plain)." Josephus omits the chronological indication common to MT and LXX 5:10, i.e. "on the fourteenth day of the month at evening."

48 This phrase lacks an equivalent in Josh. 5:10-11; it serves to highlight the contrast between the Israelites' current state now they have entered the Cisjordan and their earlier privations (cf. the reference to the place name "Galgala" [Freedom] as reflecting the people's sense of being free of "their miseries in the desert" in 5.34; see n. 45).

49 Josephus anticipates this reference to the inhabitants from 5:12b which states, in a reiteration of the content of 5:11, "[T] hey [the Israelites] ate of the fruit of the land of Canaan that year."

50 Compare the differing formulations used in MT ("And on the morrow after the Passover, on that very day, they ate of the produce [מעעבור] of the land, unleavened cakes and parched grain [מצות וקלוי]") and LXX ("and they ate of the grain [бítov] of the earth unleavened $[a ̈ \zeta v \mu \alpha]$ and new ears $\left[\nu \epsilon^{\prime} \alpha\right]$ ). Josephus uses the same term for "grain" [бítos] as does LXX.

51 This appendix to the notice of 5:11 on Israel's eating of "the produce of the land" lacks a biblical parallel. Together with the historian's previous insertion on the people's being now provided with everything they had previously lacked it serves to highlight the contrast between their current situation and their time in the desert (see n. 48). In addition, the appendix introduces the theme of the "booty" that the Israelites derive from their conquest of the land that recurs throughout Josephus' account of the conquest; see 5.32, 48, 62 . 


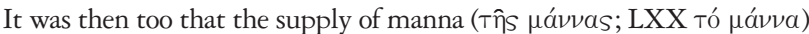
ceased which had served them for forty years..$^{52}$

The biblical account of the immediate sequels to Israel's passage of the Jordan concludes in Josh. 5:13-15 with the mysterious episode of Joshua's encounter with the sword-bearing "commander of the army of the Lord" (called "the angel who was sent from the Lord" in Tg.) who commands him (v. 15) to remove his shoes given the holiness of the spot on which he is standing. Josephus passes over this incident without a trace, ${ }^{53}$ proceeding directly (5.22) to the beginning of his account (5.22-32//Joshua 6) of the overthrow of Jericho.

\section{CONCLUSION}

By way of conclusion to this essay, I return to my opening questions in order to sum up my findings concerning them. Given both Josephus' omission of the bulk of the content of Joshua 3-5 in Ant. 5.16-21 as well as the presence of so much Sondergut in his version, one would not expect much in the way of relevant data regarding my first question on the textual affinities of Josephus' version. And, in fact, our study

52 From his rendering of 5:12 Josephus omits the double reference - repetitious of what has already been stated in 5:11 — to the Israelites' eating of the produce of the land. Whereas both Josephus and the Bible relate the cessation of the manna prior to the overthrow of Jericho (Joshua 6//Ant. 5.22-32), Pseudo-Philo (L.A.B. 20.8) mentions the former happening only after his (very summary) account of the city's fall in 20.7 , likewise dating the manna's disappearance in vague terms to "after Moses died."

53 Feldman (1998:456) explains the omission in terms of the historian's tendency to downplay the miraculous element in his retelling of the Book of Joshua as a whole. As further factor at work here could be the incident's lack of narrative function within its context: the episode ends, quite anticlimactically, with Joshua's removing his shoes $(5: 15 \mathrm{~b} \mathrm{MT},>\mathrm{LXX})$ as instructed by the apparition in 5:15a, and nothing further is said of their encounter in the rest of the book. While PseudoPhilo, like Josephus, has no equivalent to the episode recounted in Josh. 5:1315, the "Samaritan Chronicle No. 2" (a work of uncertain and controverted date) amplifies the biblical story, supplying the heavenly commander with an extended speech subsequent to Joshua's removal of his shoes that consists of instructions (drawn from Josh. 6:2-5) for Israel's upcoming move against Jericho; see Macdonald (1969:82). 
yielded relatively little in this regard. The following items are, however, of potential relevance for the question of the text-form(s) of the Book of Joshua used by Josephus. ${ }^{54}$ His distinguishing between the "priests" and "Levites" in 5.17 corresponds to the LXX reading ("priests and Levites") in Josh. 3:3 as against MT's "Levitical priests" (see n. 19). Similarly, in 5.21 he uses the same word, i.e. oítos ("grain") for that which the Israelites consume as does LXX 5:11, whereas this word lacks a clear-cut counterpart in MT (see n. 50). Finally, Josephus' situating the construction of the "altar" and the sacrifices called for by Moses in Deut. 27:5-7 at a earlier point than either MT or LXX Joshua, has, as pointed out in n. 41, a certain parallel in the sequence of 4QJosh ${ }^{\mathrm{b}}$. These findings, limited as they admittedly are, do suggest that Josephus had available various text-forms of Joshua 3-5.

It is possible to say considerably more on the further question of Josephus' rewriting techniques in 5.16-21. Of such techniques, the historian's abbreviation of the biblical material is clearly the most conspicuous. Whole segments of the source narrative (the fear of the kings [5:1], the circumcision of the people [5:2-9], and Joshua's encounter with the Lord's "commander" [5:13-15]) simply disappear in his version. Josephus, moreover, significantly compresses most of the remaining material of Joshua 3-5, i.e. the preparations for the crossing (compare $3: 1-13$ and 5.16), the crossing itself (compare 3:14-17; 4:10b-18 and 5.17-19), and the motif of the memorial stones (compare 3:12; 4:110a,19-21 and 5.20a). Indeed, the only element of the biblical narration to be given approximately "equal treatment" by Josephus is the celebration of Passover and the associated cessation of the manna (compare 5:10-12 and 5.20b-21). ${ }^{55}$

54 On this wider question, see Nodet (1995:xiii-xiv) who concludes that Josephus' primary source for his account of Joshua in Ant. 5.1-119 was a Hebrew text with much closer affinities to MT than to LXX.

55 Josephus' drastic reduction of the content of Joshua 3-5 is carried still further by Pseudo-Philo who in L.A.B. 20 limits himself to reproducing (20.8) a single item from that entire complex, i.e. the cessation of the manna, likewise mentioning this after rather than before the overthrow of Jericho (see n. 52). By contrast the "Samaritan Chronicle No. II" offers an elaborated version of the three chapters, citing, e.g., the prayers chanted by the priests as they carry the ark and attributing a more extended discourse to the Lord's "commander" than does Josh. 5:15 (see n. 53). 
At the same time, Josephus' abridgement of the Bible's account goes together with the introduction by him of a number of additions to/amplifications of this. These include: the Israelites' "fear" in the face of their upcoming passage and the reasons for this (see 5.16), the extended list of the components of Israel's line of the march (compare $3: 14$ and 5.17), the description of the priests' "footing" in the Jordan (compare 3:5, 17 and 5.18), the distance indications of 5.20a (compare 4:19), the references to the Israelites' new-found plenty (compare 5:10-11 and 5.21a), and the appended remark on the duration of the manna at the end of 5.21b (compare 5:12).

Another of Josephus' rewriting techniques evidenced by 5.16-21 is his transfer of elements of the biblical narrative to new contexts within his own version. Thus, he anticipates the notice on Israel's advance to the Jordan of Josh. 3:1, including this within his rendition of Joshua 2 in $5.4 \mathrm{~b}$ (see n. 11). Conversely, the reference to the three days' wait at the crossing point $(3: 2)$ is "delayed" to a later moment in the proceedings (see 5.17), i.e. until after the divine communication of 3:78 (//5.16 in fine). In contrast to the sequence of Joshua 3-4, Josephus speaks of the memorial stones only after the crossing of the Jordan has been completed (compare 3:12; 4:1-10a, 19-24 and 5.20a). Likewise, mention of the place name "Gilgal" of 4:19 and the explanation of its meaning (5:9) are held over by him until a later point; see 5.34.

Finally, Josephus modifies the material of Joshua 3-5 in still other ways. He, e.g., avoids the segment's recurrent use of "Lord" as a divine

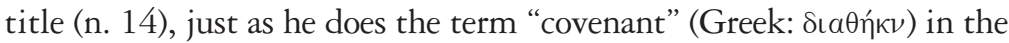
phrase "ark of the covenant" (see n. 18). Conversely, he applies (5.20) the title of "prophet" to Joshua, as the Hebrewe Bible itself never does (see n. 38). The direct address used for God's words to Joshua in 3:78 is recast as indirect in 5.16 (see n. 14). On a content level, the initiative attributed to the "officers" following a three-day wait in $3: 2$ is transferred (5.17) to Joshua himself, once he has waited two days. The stoppage and piling up of the Jordan's current spoken of in 3:13,15 becomes a "diminution" of the river's flow in 5.16, 18, while the standing stones that Joshua erects in 4:21 are, perhaps under the influence of a Vorlage à la 4QJosh ${ }^{\mathrm{b}}$ (see n. 41), turned into a "altar" for sacrifice. In addition, when Josephus comes to speak (5.34) of the meaning of the name "Gilgal" (Galgala), he supplies a different explanation of this than does Josh. 5:9 (see n. 45). 
Josephus' application of the above rewriting techniques to the material of Joshua 3-5 yields a version of events that differs in numerous respects from the biblical one. His many omissions and abbreviations of source items results in a streamlined, easier to follow account of the crossing and its initial sequels. At the same time, he does introduce a rather detailed response (see 5.16) to a question suggested by - but left unanswered - in Joshua 3-4, i.e. why should the crossing of a rather minor stream like the Jordan have posed such a problem for the Israelites that God himself needed to become involved (see n. 11)? Overall, the role of the Deity and of the miraculous is notably reduced in Josephus' retelling where, e.g., there is only a single divine communication (see 5.16, as compared with the three recorded in Joshua $3-5$, i.e. $3: 7-8 ; 4: 2-3 ; 5: 2$ ), the figure of the Lord's "commander" (see Josh. 5:13-15) disappears, and the water's flow is only "diminished" rather than being stopped completely. In the same line, the potentially sensitive issue of compulsory circumcision that the narrative of Josh. 5:2-9 could pose for Gentile readers is disposed of via Josephus' omission of the whole episode (see n. 45). As for the story's human protagonist, Joshua, his stature is somewhat heightened by Josephus. After the wait by the Jordan it is he, rather than the "officers" who take the initiative (compare 3:2 and 5.17). Subsequently, he is awarded (5.20a) the title "prophet" and represented as sacrificing on the altar he has erected, neither of these items having a counterpart in the source verse, Josh. 4:20.56 Also the psychology of the people receives greater attention vis-à-vis the source presentation, with both their initial "fear" of the current (see 5.16,17) and their subsequent "confident" (5.18) entry into it being highlighted. The historian's ascribing, in this going beyond the LXX reading of 3:3, a distinct task to the Levites during the crossing (5.17) is likewise noteworthy, given that in many other contexts he seems to diminish the Levites' role (see $\mathrm{n}$. 19). And lastly, Josephus' version of the notices on the Passover observance of 5:10-11 in 5.21a accentuates the contrast between Israel's current bounty in the land and its earlier deprivations (see nn. 48, 51).

Brief as it is, Ant. 5.16-21 offers a range of insights into Josephus' procedure as a rewriter of the biblical account, i.e. as one who com-

56 On Josephus' portrayal of Joshua overall, see Feldman (1998:443-460). 
bines fidelity to the basic Scriptural story line with much freedom in the handling of its details.

\section{BIBLIOGRAPHY}

ABEGG, M. (jr). et al. (EDs.)

1999. The Dead Sea Scrolls Bible. San Francisco: HarperSanFranciso.

BEGG, C.T.

1993. Josephus' account of the Early Divided Monarchy (AJ 8,212-420). Leuven: University Press/Peeters.

1997. The Asjordanian altar(s) and their associated rites according to Josephus.

Biblische Zeitschrift 41:192-211.

2004. The Levites in Josephus. Hebrew Union College Annual 75:1-22.

2005. Flavius Josephus Judean Antiquities 5-7. Leiden: Brill.

2005a. The fall of Jericho according to Josephus. Estudios Bíblicos 63:323-340.

2005. The Rabah story according to Josephus. Liber Annuus 55:113-130.

BOLING, R.G. \& WRIGHT, G.E.

1982. Josbua. Garden City, New York: Doubleday.

Brooke, A.E. \& Maclean, N. (Eds.)

1917. The Old Testament in Greek I:IV Joshua, Judges and Ruth. Cambridge: University Press.

ColautTi, F.M.

2002. Passover in the work of Josephus. Leiden: Brill.

FELDMAN, L.H.

1990. Prophets and prophecy in Josephus. Journal of Theological Studies 41:386402.

1998. Josephus's interpretation of the Bible. Berkeley: University of California Press.

GRYSON, R. (ED.)

1994. Biblia sacra iuxta vulgatam versionem. Stuttgart: Deutsche Bibelgesellschaft.

Harrington, D.J. \& Saldarini, A.J. (Trs.)

1987. Targum Jonathan of the Former Prophets. Wilmington, Del.: Glazier. 
Harvey, G.

1996. The true Israel: uses of the names Jew, Hebrew and Israel in Ancient Jewish and Early Christian literature. Leiden: Brill.

JAUBERT, A. (TR.)

1960. Origène Homélies sur Josué. Paris: Cerf.

Macdonald, J. (Tr.)

1969. The Samaritan Chronicle No. II (or Sepher Ha-Yamim). From Joshua to Nebuchadnezzar. Berlin: De Gruyter.

MARCUS, R. (TR.)

1934. Josephus V. Cambridge, Mass: Harvard University Press/London: Heinemann.

Moatti-Fine, J. (Tr.)

1996. Jésus (Josué). Paris: Cerf.

Nodet, E. (TR.)

1995. Flavius Josèphe II: Les Antiquités Juives Livres IV et V. Paris: Cerf.

ROBERT, U. (ED.)

1900. Heptateuchi partis posterioris versio latina antiquissima e codice lugdunensi. Lyon: Rey et $\mathrm{C}^{\mathrm{ie}}$.

SPerber, A. (ED.)

1959. The Bible in Aramaic II. Leiden: Brill.

SPILSBURY, P.

1998. The image of the Jew in Flavius Josephus' paraphrase of the Bible. Tübingen: Mohr Siebeck.

UlRich, E. et al. (EDs.)

1995. Qumran Cave 4. IX: Deuteronomy, Joshua, Judges, Kings. Oxford: Clarendon.

Keywords

Joshua 3-5

Josephus

Rewritten Bible
Trefwoorde

Josua 3-5

Josefus

Herskrewe Bybel 